Session 2159

\title{
Teaching Instrumentation and Data Acquisition at the Federal University of Viçosa in Brazil
}

\author{
Hartono Sumali, Daniel Marçal-de-Queiroz \\ Purdue University, West Lafayette, IN/Federal University of Viçosa, MG, \\ Brazil
}

\begin{abstract}
ABE 430 Instrumentation and Data Acquisition had been taught for two years at Purdue University when the Federal University of Viçosa invited the instructor to teach that course in Brazil. Based on the instructor's experience in teaching the course there, this paper offers suggestions on how to successfully address the problems associated with teaching a hands-on laboratory course away from the home institution where the course was established. The problems included content adaptation, equipment availability, laboratory setup, scheduling, instruction methods, language barrier, funding, and a few other problems. Advantages and compromises associated with the international adaptation of the course are discussed. It is hoped that this paper will help create a model for international teaching collaboration.
\end{abstract}

\section{Introduction}

In the last decade or so, a plethora of publications have addressed the importance of preparing engineering students for the internationalization of their profession ${ }^{1}$. In most of those publications, international or global education means students studying outside their countries to prepare them for the global business world ${ }^{2,3}$. Very few articles address the training of engineering educators to prepare them to train engineering students for globalization. Part of this faculty preparation is to study globalization of education from the literature ${ }^{4,5,6,7,8}$. However, many of the studies show that successful international endeavor requires plenty of face-to-face interactions ${ }^{9}$. Ideally, the educators themselves must gain real teaching experience outside his/her own country. The first purpose of this paper is to promote awareness of the faculty preparation aspect of international education. The second purpose is to present lessons learned by an American faculty member from teaching a laboratory-intensive course outside the U.S. 


\section{The Course at Purdue}

In the Agricultural and Biological Engineering Department at Purdue University in West Lafayette, Indiana, the Instrumentation and Data Acquisition course was started in the fall semester of 1998 as the Department's response to feedback from its alumni in industry. The course learning objectives are:

1. To understand the principles of operation and limitations of common measuring instruments.

2. To model transducers and their operating conditions

3. To design systems for the acquisition, analysis, and communication of data

4. To gain awareness of economical and social aspects of instrumentation systems and of presentation of information.

As in most other instrumentation and data acquisition courses, students in the class learn about transducers for pressure, flow, temperature, humidity, force, etc. They also build signalconditioning circuits such as a strain gage signal conditioner with a Wheatstone bridge, operational amplifiers, and active filters. Other experiments include interfacing with global positioning systems (GPS) and various other sensors used in precision agriculture. More information about this course is available in the literature ${ }^{10}$. Details of the course topics, including lecture notes and laboratory handouts are linked to the class home page ${ }^{11}$. The following paragraphs present a sampling of the course materials.

At Purdue, this three-credit-hour course is conducted in 15 weeks, two hours of lectures and two hours of laboratory exercises each week. Two of the laboratory sessions are visits to companies to study their data acquisition systems. The class home page ${ }^{11}$ is linked to all lecture notes, homework assignments and solutions, practice problems, grades, etc. Students in the course spend about half of the structured class time on hands-on exercises. Every lecture topic is reemphasized with a laboratory exercise in the session immediately following the lectures.

The first few laboratory exercises are building and testing elementary electronic circuits commonly required in instrumentation and data acquisition. For these exercises, the course provides common electronic tools and components such as multimeters, oscilloscopes, breadboards, data acquisition PCs, and function generators.

Transducers used by the students are those commonly used in industry, including pressure transducers, turbine and positive-displacement flow meters, rotameters, thermocouples, resistance temperature detectors, and thermistors. Other instruments in the laboratory include relative humidity transducers, programmable logic controllers (PLC), and differentially corrected global positioning systems (DGPS). Most of the transducers are mounted on a special instrumentation and data acquisition laboratory test stand. The test stand also has machinery hydraulic components such as flow control valves, needle valves, pressure relief valves, and a hydraulic accumulator. Currently, the laboratory has three such test stands. The test stand is shown in Figure 1, and described in detail by Brown and Sumali ${ }^{12}$. 


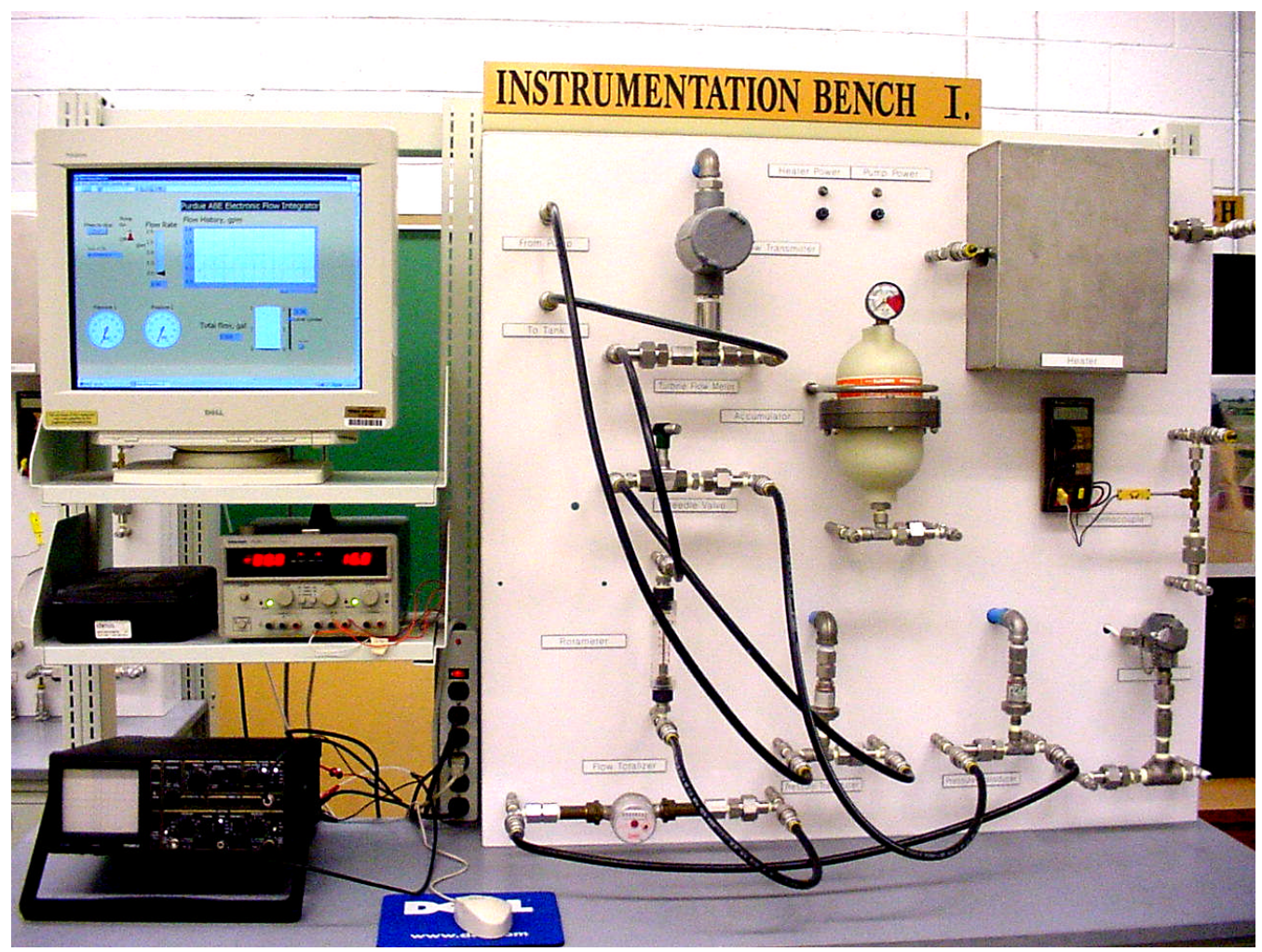

Figure 1 Purdue's Instrumentation and Data Acquisition Laboratory Test Stand.

Graphical programming is learned for three weeks in this course using LabVIEW ${ }^{\mathrm{TM}}$ Hands-On Course manual ${ }^{13}$. With this software, students create their own "virtual instruments". An example of a virtual instrument is as an oscilloscope with mouse-driven control switches and buttons on a PC screen. Students create this oscilloscope in the class. With a data acquisition board, the oscilloscope functions in the same manner as a "real" oscilloscope. However, the same hardware used to build the oscilloscope can be reprogrammed to function as a spectrum analyzer and other instruments. In essence, graphical programming converts the PC into various instruments designed by the programmer. An advantage of virtual instruments over "hard-wired" instruments is that the former are much more versatile and economical.

\section{Groundwork for Adopting the Course in Brazil}

In 2000, ABE 430 Instrumentation and Data Acquisition had been taught for two years at Purdue University, and had made a few impacts in industry and education, including some industrial application of the skills. A graduate from that course was awarded the highest scholarship from the Instrument Society of America (ISA) ${ }^{14,15}$. One of the criteria for the scholarship was potential to be a significant contributor to instrumentation engineering. In that year, the Federal University of Viçosa (Universidade Federal de Viçosa, UFV) invited the instructor to teach that course in Brazil.

Before inviting Professor Sumali to teach the course at UFV, Professor Marçal-de-Queiroz had obtained funding for the laboratory equipment from the federal government of Brazil. Later he visited Purdue and gathered information on Professor Sumali's Instrumentation and Data Acquisition course at Purdue. He then worked with Professor Sumali to prepare for the teaching 
of the course at UFV. To cover Professor Sumali's travel, accommodation and remuneration, Professor Marçal-de-Queiroz obtained funding from the Brazilian National Council for Scientific and Technological Development (CNPq). In consultation with Professor Sumali, Professor Marçal-de-Queiroz prepared the laboratory for the course at UFV. Then he invited Professor Sumali to teach the course at UFV.

\section{Scheduling}

The months of May through July are the time when most Purdue professors do not have classroom duties. In general, the (northern hemisphere) summer is the best time for North American professors to work outside their institutions. Meanwhile, in that time of the year classes are active in Brazil. Therefore, Professors Sumali and Marçal-de-Queiroz conducted the course from May to July of 2000.

Like many summer classes in North America, the instrumentation and data acquisition course was conducted under an intensive course schedule. At Purdue, the total contact time of the course is 15 weeks times 4 hours/week $=60$ hours. To give the same contact time, the course at UFV is conducted in 20 sessions of three hours. About half of the contact hours are lectures, and the other half are laboratory exercises. This proportion was also maintained at UFV.

Three hours turned out to be a very good length for the laboratory sessions. In the middle of the sessions, a 15-minute break was taken. However, three-hour chunks of time are not suitable for lectures. Therefore, ten-minute breaks were taken after 50 minutes or a half hour.

\section{Sample Experiments and Their Adaptation}

Most of the lecture topics and materials are readily adaptable to the educational objectives of UFV. The most important reason for modifying the course details is the different availabilities of equipment. Another reason is the difference in educational objectives between the two departments. The department at UFV is equivalent to what is known in the U.S.A. as Agricultural Mechanization (Mecanização Agrícola in Portuguese), which requires more practical skills and less mathematical rigor than in the curricula of most U.S. engineering departments. This difference is addressed by reducing the calculus of such topics as first-and second-order dynamics, error propagation, electronic filters, etc, and replacing it with more lab exercises in the installation of strain gages, data acquisition hardware, radar speed sensor, etc.

An example of the above issue is the adaptation of a strain gage experiment. At Purdue, this experiment requires students to apply their knowledge of load cells, Wheatstone bridge, operational amplifiers, active filters, calibration, and virtual instrumentation, to design and test a load cell and its signal conditioner as shown in Figure 2. A virtual instrument on the PC displays the weight on the computer screen. The virtual instrument can also be put into calibration mode, where it obtains the calibration factor from voltage to weight by regression analysis, and removes the tare or other initial offset reading. Given the specifications, students design the beam dimensions and the values of the resistors and capacitor, fabricate the beam in the shop, attach the strain gages, build the electronic circuit on a breadboard, and create the virtual instrument by programming the data acquisition system. 


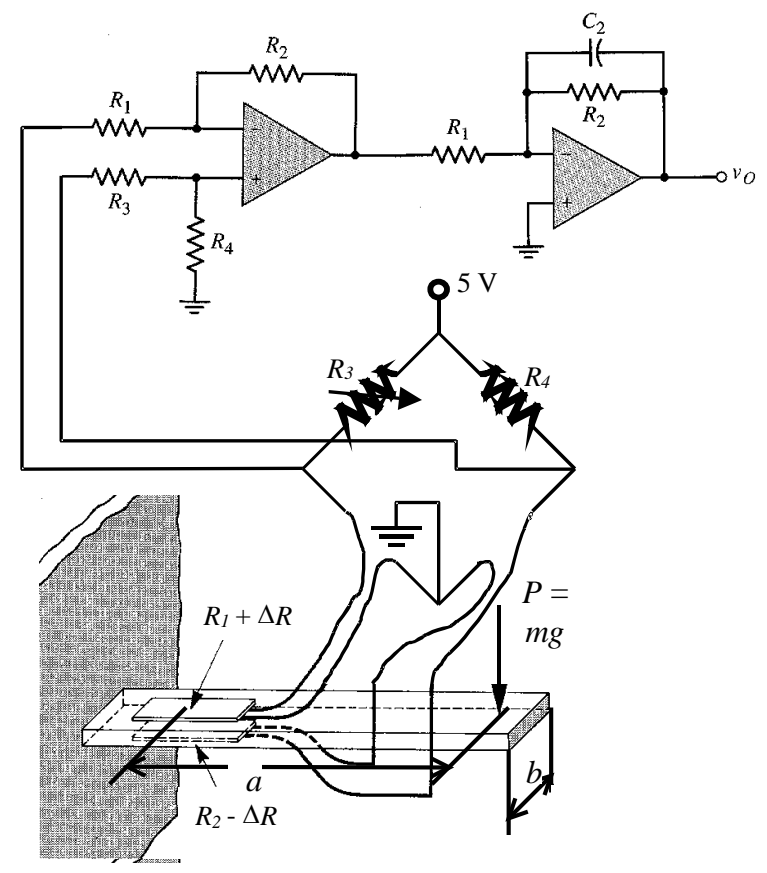

Figure 2 Load Cell Transducer Experiment at Purdue.

At UFV, students used an off-the-shelf load cell and strain signal conditioner. They spent more time configuring and installing the data acquisition hardware and programming the virtual instrument. The UFV students also played a more active role in preparing the laboratory for the experiment. The virtual instrument written by a UFV student is shown in Figure 3, with the words translated from Portuguese into English. The virtual instrument can be used to calibrate the load cell using standard weights. The known weight of the standard is typed in on the screen. When the Record button is pressed, this weight and the load cell reading are saved in a spreadsheet file. After many different standard weights are used, the stop switch is flipped. Then the virtual instrument reads the spreadsheet file and performs a linear regression analysis to obtain a correction factor for the load cell reading, thus calibrating the measurement system. 


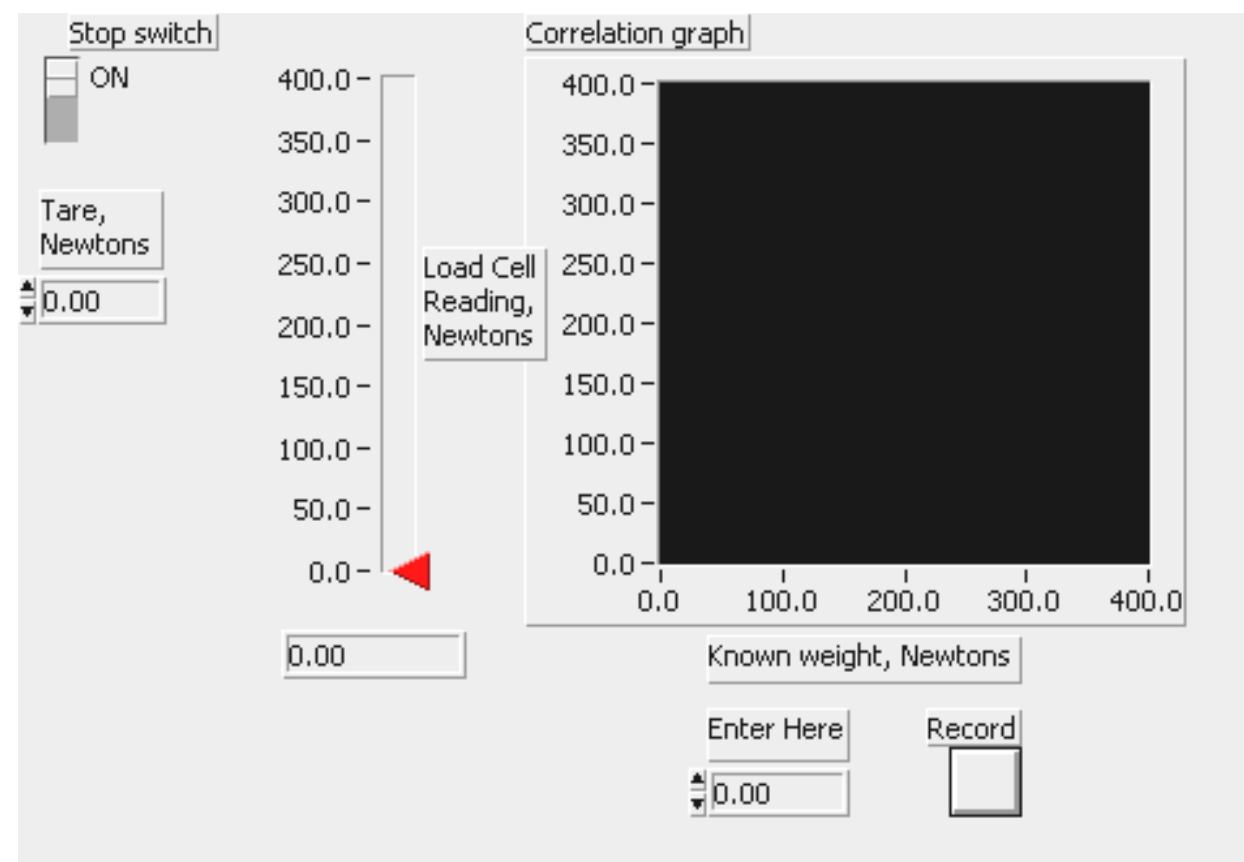

Figure 3 Load Cell Calibration Experiment at UFV. Virtual Instrument.

Different equipment availability also required adaptation of the course. Having established the course laboratory for two years, Purdue ABE students had been using the test stand shown in Figure 1. UFV had significant laboratory equipment, but had not built an instrumentation test stand like Purdue's. Experiments that were designed for Purdue's test stands had to be modified. For example, the pressure experiment was adapted to be as shown in Figure 4.

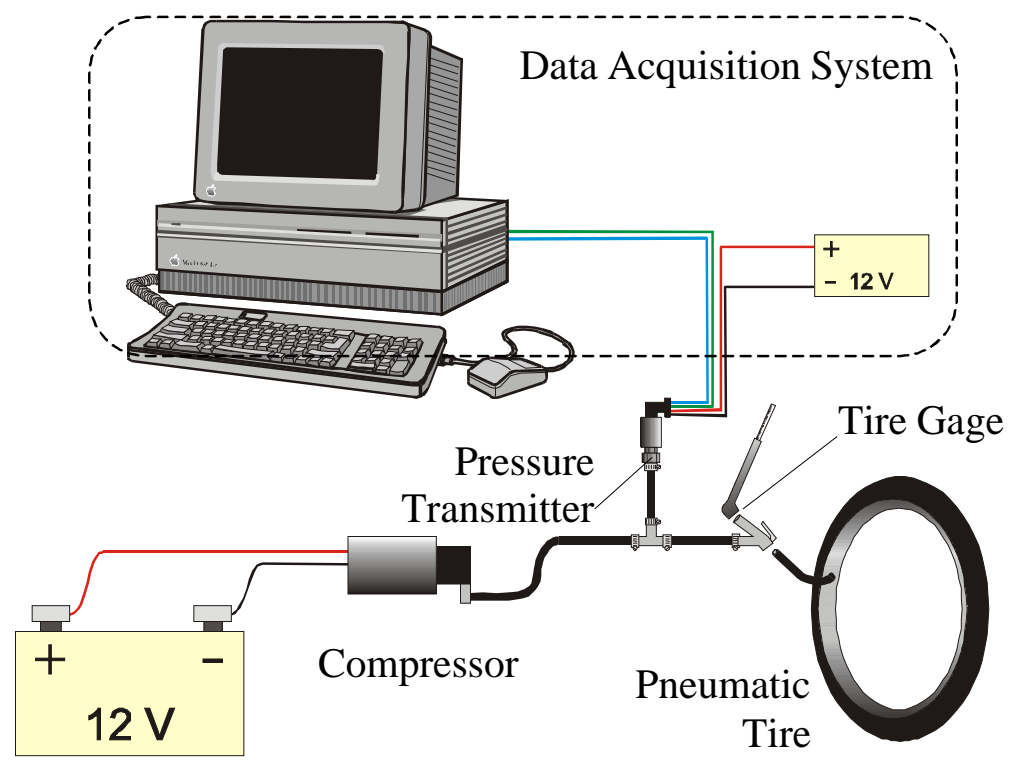

Figure 4 Tire Gage Calibration Experiment at UFV. 
The purpose of the modified experiment is to calibrate and estimate the precision of a tire gage. A precision pressure transducer is used as a standard. Air pressure is generated by a compressor and is stored in a large pneumatic tire. This pressure is measured by a pressure transducer and by the tire gage to be calibrated. The virtual instrument shown in Figure 5 acquires the pressures and performs a linear regression analysis to calibrate the tire gage and estimate its precision.

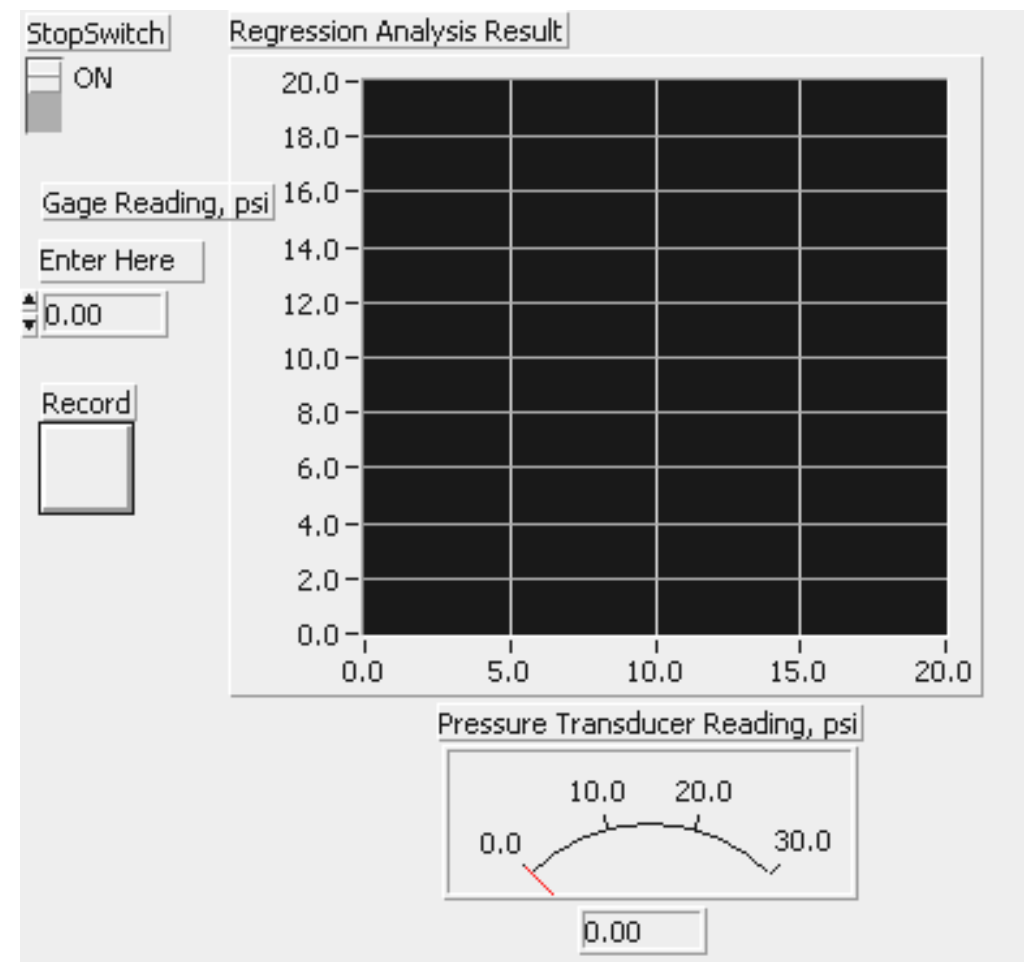

Figure 5 Virtual Instrument Panel for Tire Gage Calibration Experiment.

Another experiment that was done at UFV but not at Purdue was interfacing a radar sensor for tractor velocity with a data acquisition system. A major part of this exercise is to program the counter and timer of the data acquisition card to count the rate of pulses from the radar sensor. The experiment introduces the concept of gates, clocks, and frequency measurement in counters and timers. Other topics of the course taught at UFV, along with descriptions of the laboratory experiments, are listed on the class web page ${ }^{16}$.

\section{Overcoming Language Barriers}

For an American professor teaching her or his course in a country whose language is not English, language barrier can be a significant problem. In many countries all over the world, most people in higher education speak at least some English. If an American professor is invited to teach at a non-English-speaking institution, it is likely that at least a few people in the host institution speak English and can help the American professor. It is true in many cases that the American professor can teach in English and be understood by many of the students in the class. However, as experience showed. The few students who do not speak English become disadvantaged victims. Even students who speak English as a second language may not feel comfortable to communicate their questions or remarks to the professors. If the American professor speaks no 
other language than English, she or he may not understand the students. In particular, the professor will likely not understand students' assignment papers well enough to grade them. Effective international education must provide means of overcoming language barriers ${ }^{17}$. The authors suggest a few methods to overcome language barriers in the classroom.

1. Speak the language of the students.

Ideally, an American teacher teaching abroad should teach in the language of the host country, at least in combination with English. The following tips may help prepare the teacher: Before going on a foreign assignment, learn as much of the language as possible. Be immersed in the language as much as possible; Socialize with the students and other hosts in their language.

\section{Use an interpreter.}

In most classrooms, a real-time translation system is not feasible. In that case, translation can be interleaved in the lecture. The translator must be familiar with the lecture topic. A disadvantage of this method is that translation takes valuable time from the lecture and is a wasteful duplication of teaching efforts. Another disadvantage is the risk of information distortion.

Alternatively, the interpreter can work with the teacher before the lecture to produce visual aids in the host language.

\section{Speak English. But modify your lectures.}

Here are some suggested "quick-fixes" to the language barrier problem.

a. Speak slowly and distinctly.

b. Use abundant graphics: pictures, graphs, and diagrams. In learning engineering, students spend a large proportion of the time learning and using equations and graphs. Most of these depend little on language.

c. Use active learning approaches more than lectures. Give students problems, preferably in their language, and ask them to solve the problems in the classroom. At least in engineering, students may learn more when they solve problems than when they listen to lectures.

The teacher who speaks only English will still need an interpreter to translate que stions and comments from the students.

On the first days of teaching at UFV, Professor Sumali observed that about a quarter of the students did not understand his English lectures very well. In the first few lectures, he relied heavily on an interpreter (a graduate student of UFV or sometimes Professor Marçal-deQueiroz). He also applied methods in No. 3 above. In the second week of classes, Professor Sumali started combining the above solutions with a little Portuguese. In the third week of classes, he taught almost entirely in Portuguese. He had spoken Spanish for years before, had learned Portuguese for a few months, and learned Portuguese intensely once he arrived in Brazil. 


\section{Conclusion and Recommendations}

1. The Instrumentation and Data Acquisition laboratory course at Purdue University has served as a model for starting a similar course at the Federal University of Viçosa.

2. Major issues associated with the adoption of the course to a different university were discussed in the paper.

3. Language barrier is a significant problem when an instructor is to teach in a foreign country whose language is not spoken by the instructor. However, several things can be done to alleviate or eliminate that problem.

\section{Bibliography}

1 Haara, B. "Challenging the way we learn to write for a global audience", IEEE International Professional Communication Conference. 2000. p 293-303

2 Fortenberry, N. L. "Under the jeweler's loupe: Global engineering education". Computer Applications in Engineering Education. v 4 n 2 1996. p169-172.

3 Maury, C. "International Education in French Engineering Schools. Frontiers: the Interdisciplinary". Journal of Study Abroad. v3 n2 p218-22 Fall 1997.

4 Barrows, L. C, Ed. "Internationalization of Higher Education: An Institutional Perspective." Papers on Higher Education. 95 p. 2000.

5 Davis, C., Seigel, A., and Chin, M. W. "Transfer of high technology via continuing education: A case for SouthNorth partnerships." International Journal of Continuing Engineering Education. v 2 n 2-4 1992 p 248-255

6 Evans, D. S. and Vergnaud, S. "Pedagogical Engineering in Intercultural Terms: Critical Success Factors." International Journal of Educational Management. v12 n4-5 p149-53 1998.

7 Klahr, S. C. and Ratti, U. "Increasing Engineering Student Participation in Study Abroad: A Study of U.S. and European Programs.” Journal of Studies in International Education. v4 n1 p79-102 Spr 2000.

8 Kulacki, F. A. and Krueger, E. R. Trends in Engineering Education--An International Perspective. 6 p. 1998.

9 Linna, E-K. "Evaluating and developing international cooperation," International Journal of Continuing Engineering Education. v 10 n 1-4. 2000. p 109-126

${ }^{10}$ Sumali, H., "An Instrumentation and Data Acquisition Course at Purdue University", to appear, Proceedings of the 2002 American Society for Engineering Education Annual Conference \& Exposition, Toronto, Canada.

${ }^{11}$ Sumali, H, Instrumentation and Data Acquisition Class Home Page, at http://pasture.ecn.purdue.edu/ abe591s/Fall2001.html, as posted December 14, 2001

12 Brown, R. J. and Sumali, H. "A Computer-Based Laboratory Bench for Learning Instrumentation and Data Acquisition”, ASAE Paper No. 01-3140, 9 p, 2001.

${ }^{13}$ National Instruments, LabVIEW Basics I Hands-On Course Course, Austin, TX, 1998.

${ }^{14}$ Instrument Society of America (ISA), ISA Educational Foundation, http://www.isa.org/efsrecipients.html, as accessed on January 12, 2002.

${ }^{15}$ Instrument Society of America (ISA), ISA Educational Foundation, http://www.isa.org/educationfoundation/ , as accessed on January 12, 2002.

${ }^{16}$ Sumali, H. "Aquisição de Dados e Intrumentação" (Data Acquisition and Instrumentation), class home page at http://pasture.ecn.purdue.edu/ abe591s/Brazil.html (in Portuguese), as posted December 2000.

${ }_{17}$ McGowan, U., Seton, J., and Cargill, M. "Collaborating colleague model for inducting international engineering students into the language and culture of a foreign research environment". IEEE Transactions on Professional Communication. v 39 n 3 Sep 1996. p 117-121 


\section{Biography}

Hartono Sumali obtained his Ph.D. in Mechanical Engineering from Virginia Tech in 1997, and has since been an assistant professor in Purdue University's Agricultural and Biological Engineering (ABE) Department. From 1987 to 1989 he was an instrumentation engineer for McDermott Inc., a company that builds offshore oil platforms. He has also worked for Caterpillar Inc. and the U.S. Navy. He has received several teaching awards from Purdue University and SAE International. 